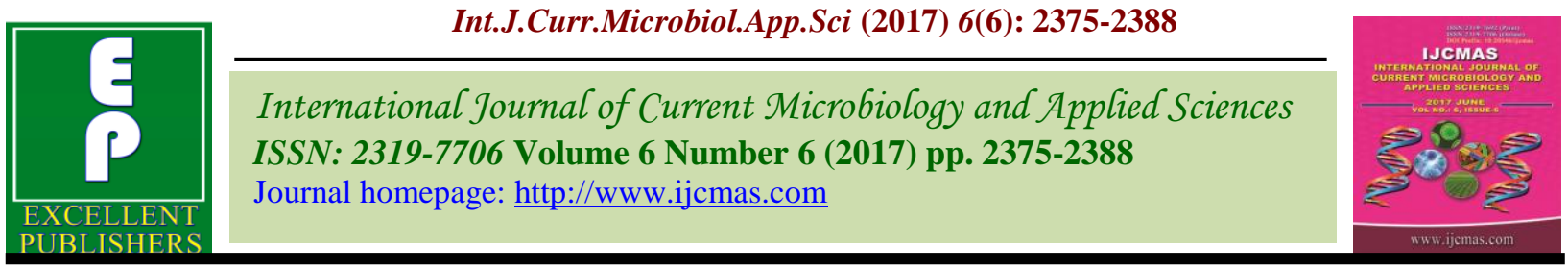

Original Research Article https://doi.org/10.20546/ijcmas.2017.606.282

\title{
Genetic Estimates and Character Association Studies in Field Pea (Pisum sativum L.)
}

\author{
B.L. Meena*, S.P. Das, B.K. Kandpal and S.V. Nagchan \\ ICAR Research Complex for NEH Region, Tripura Centre, Lembucherra - 799210, India \\ *Corresponding author
}

\section{A B S T R A C T}

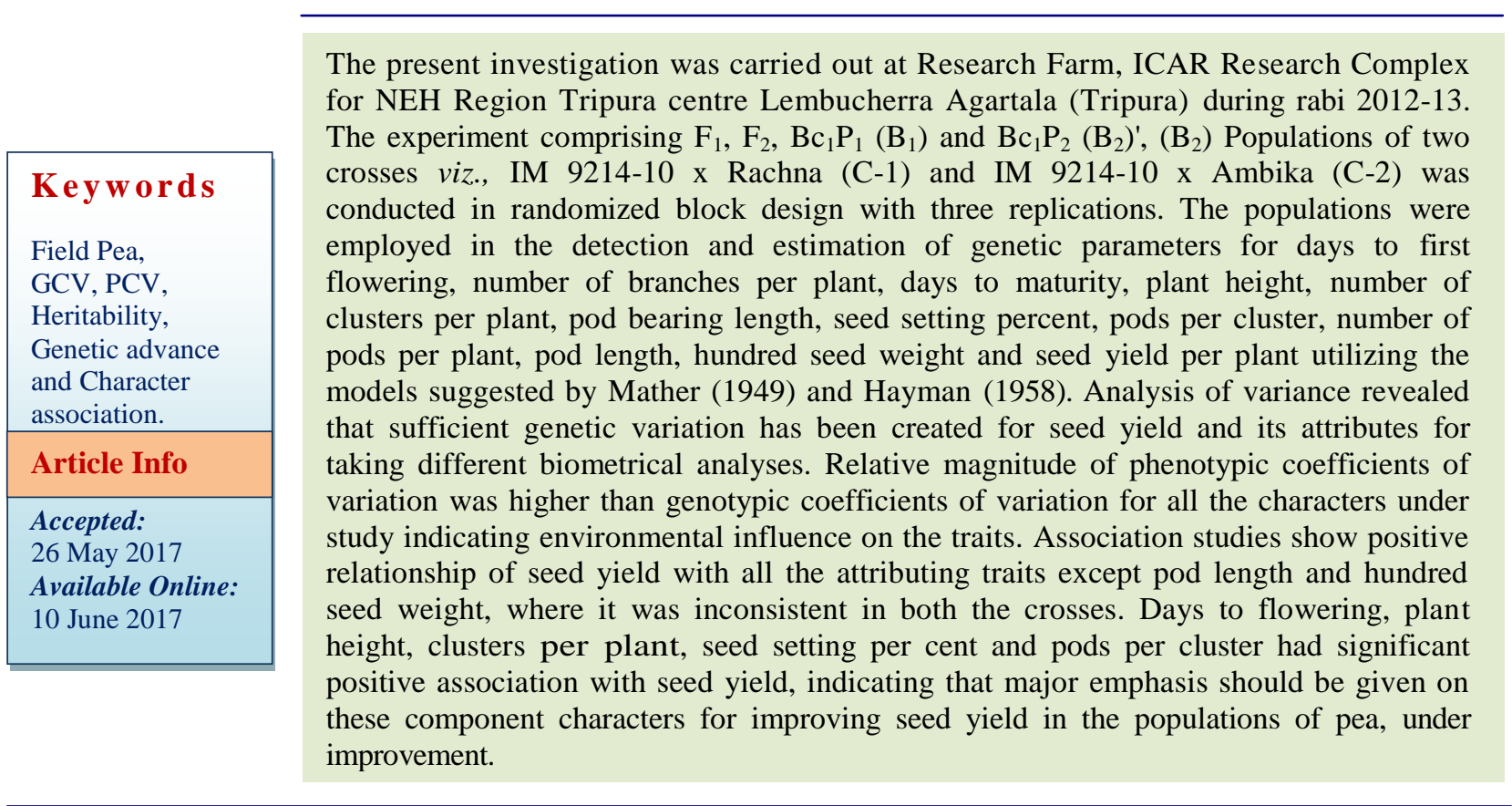

\section{Introduction}

Proteins are the essential ingredients of our food and are considered to be building block of our body. The deficiency of protein particularly in growing children and nursing mothers causes "Protein caloric malnutrition" IPCMI. Proteins constitute about 20 percent of our body weight and are derived from the dietary foods (Swaminathan, 1990). Pulses are considered to be the cheapest and economic source of protein. However, the availability of pulses had declined from $64 \mathrm{~g}$ to less than $37 \mathrm{~g}$ as against the recommendation of $80 \mathrm{~g}$ per capita per day. It is estimated that the Indian population will touch nearly 1350 million by 2020 A.D. and country' would then need a minimum of 30.0 million tones of pulses, as against today's pulses production of 28.17 million tones (Anonymous, 2013). Among the major pulse crops grown in India, field pea or dry pea (Pisum sativum L.) belongs to family leguminoceae and sub family Papilionaceae 
is considered to be the native of Ethiopia, the Mediterranean and Central Asia. It is a nutritious and protein rich (19.6\%) crop, mostly used for green and dry seeds. Hence, pea is categorized as vegetable type and field pea. The area of field pea in India is about 0.76 million hectares with annual production of 0.84 million tones and productivity of $1100 \mathrm{~kg} \mathrm{ha}^{-1}$ (Anonymous, 2013a).

Its area, production and productivity in the state of Tripura are 1028 hectare $897 \mathrm{mt}$ tonnes and $873 \mathrm{~kg} / \mathrm{ha}$ respectively, (Anonymous, 2013b).

To meet out challenging demand of pulses it has became necessary to boost up their production in the country. Field pea has high production potential of more than 2.0 tons per ha under better agronomic management (Anonymous, 2013c). Field pea, very much response to low soil $\mathrm{pH}$ and one/two irrigations hence, there is plenty of scope for its horizontal and vertical expansion in rice based cropping system of Tripura. Relatively this crop dose not has much problem of pest and diseases except powdery mildew, to which genetic resistance is available.

The farmers of the state are small and marginal hence, there is urgent need to give them varieties which yield better even under average agronomic management. Dwarf types have greater potential under one or two irrigations. Hence, there is need to combine together desirable gene(s) from tall and dwarf types for evolving high yielding, disease resistant and widely adopted varieties for the state of Tripura. To attain the goal, the information on genetic architecture of yield and its attributing traits is essentially needed. Hence, the present study has been undertaken to generate basic information in relation to genetic improvement in seed yield. Estimates of parameters of variability importantly, heritability and genetic gain are reliable indicators for improvement of characters in a particular genetic material through selection. Since, the selection for highly heritable characters is more effective, therefore, heritability along with other parameters can be used in predicting the gain for a given selection intensity and expected genetic gain further gives the idea of the extent of improvement in a character through simple selection. Moreover, selection for yield and quality traits can be better achieved if the information with respect to correlation between such traits is also available with a better understanding of the association between the relevant characters with yield (Kumar et al., 2015). The present study therefore, was taken up to estimate the parameters of variability and character association in pea so that the desired targets are achieved.

\section{Materials and Methods}

The present investigation was carried out at Research Farm, ICAR Reesearch Complex for NEH Region Tripura centre Lembucherra Agartala (Tripura) during rabi 2012-13. The experiment comprising $\mathrm{F}_{1}, \mathrm{~F}_{2}, \mathrm{Bc}_{1} \mathrm{P}_{1}\left(\mathrm{~B}_{1}\right)$ and $\mathrm{Bc}_{1} \mathrm{P}_{2}\left(\mathrm{~B}_{2}\right),\left(\mathrm{B}_{2}\right)$ Populations of two crosses viz., IM 9214-10 x Rachna (C-1) and IM 9214-10 x Ambika (C-2) was conducted in randomized block design with three replications. The populations were employed in the detection and estimation of genetic parameters for days to first flowering, number of branches per plant, days to maturity, plant height, number of clusters per plant, pod bearing length, seed setting percent, pods per cluster, number of pods per plant, pod length, hundred seed weight and seed yield per plant utilizing the models suggested by Mather (1949) and Hayman (1958). In each replication, each genotype was sown in a plot size $2.0 \times 0.90 \mathrm{~m}^{2}$ consisting of three row. The row to row and plant to plant distance was $30 \mathrm{~cm}$ and $10 \mathrm{~cm}$, 
respectively. Five competitive plants were selected at random in $\mathrm{P}_{1}, \mathrm{P}_{2}, \mathrm{~F}_{1}, \mathrm{BC}_{1}$ and $\mathrm{BC}_{1}$ while 20 plants in $F_{2}$ for recording the observations on number of branches per plant, plant height, number of clusters per plant, pod bearing length, seed setting percent, pods per cluster, number of pods per plant, pod length, hundred seed weight and seed yield per plant. Data on days to $50 \%$ flowering and Days to maturity was however recorded on whole plot basis. The crop was raised as per the recommended package of practices. Analysis of variance was carried out as per the procedure given by Panse and Sukhatme (1985). Genotypic and phenotypic correlation coefficients of variability were estimated according to the Burton and Devane (1953) by using the following formulae.

$\mathrm{PCV}=\frac{\sqrt{\sigma 2_{p}}}{\mathrm{~s}} \times 100 \mathrm{GCV}=\frac{\sqrt{\sigma 2_{g}}}{\mathrm{~s}} \times 100$

Where,

PCV = Phenotypic Correlation Coefficient, GCV = Genotypic Correlation Coefficient $\sigma^{2} \mathrm{~g}=$ Genotypic variance $=($ Mean sum of squares due to genotypes - Error mean sum of squares) $\div$ Replications

$\sigma^{2} \mathrm{p}=$ Phenotypic variance $=\sigma^{2} \mathrm{~g}+\sigma^{2} \mathrm{e}$

$\sigma^{2} \mathrm{e}=$ Environmental variance $=($ Error mean sum of squares) $\div$ Replications

$\overline{\mathrm{x}}=$ General mean

PCV and GCV were classified as suggested by Sivasubramanian and Menon (1973).

$\begin{array}{lll}\text { Less than } 10 \% & = & \text { Low } \\ 10-20 \% & = & \text { Moderate } \\ \text { More than } 20 \% & = & \text { High }\end{array}$

\section{Results and Discussion}

Analysis of variance was carried out separately for cross and characters (Table 1). The mean sum of squares due to treatments (different generations) were highly significant for all the characters except number of branches per plant and hundred seed weight in cross-1, and pod length and pods per cluster in cross-2. The mean performance of six generations for each of the twelve characters is given in table $2 . F_{1}$ means as compare to their parental values varied in magnitude from cross to cross and character to character. Similarly, $F_{2}$ means also deviated from $F_{1}$ means. In general, backcrosses gave superior performance as compare to their parents for seed yield and other important attributes related to seed yield.

Heritability in narrow sense and genetic advance over mean estimated as percentage of mean for all the characters and cross wise (Table 4).

\section{Cross-1}

Nine characters viz., days to flowering $(75.70 \%)$, days to maturity $(83.30 \%)$, plant height (99.90\%), pod bearing length $(98.80 \%)$, number of clusters per plant (97.00\%), seed setting percent $(87.90 \%)$, number of pods per plant $(99.70 \%)$, hundred seed weight $(84.80 \%)$ and seed yield per plant $(97.60 \%)$ expressed high heritability, while number of branches per plant $(52.64 \%)$, pods per cluster $(47.80 \%)$ and pod length $(45.40 \%)$ expressed moderate heritability under study.

Genetic advance as percentage of mean was found to be the highest for number of pods per plant $(78.86 \%)$, followed by seed yield per plant $(69.20 \%)$, pod bearing length $(57.95 \%)$, plant height $(54.20 \%$.), number of clusters per plant $(51.30 \%)$. It was low for pods per cluster $(10.00 \%)$, hundred seed weight $(9.30 \%)$, seed setting percent $(7.25 \%)$, pod length $(5.65 \%)$, number of branches per plant $(5.36 \%)$, days to first flowering $(3.74 \%)$ and days to maturity (1.66\%) (Table 3 ). 


\section{Cross-2}

Nine characters viz., days to flowering $(66.30 \%)$, days to maturity $(63.30 \%)$, plant height (98.8).\%), pod bearing length (94.60\%), number of clusters per plant (97.80\%), seed setting percent $(77.00 \%)$, number of pods per plant $(90.00 \%)$, hundred seed weight $(82.50 \%)$ and seed yield per plant $(96.40 \%)$ expressed high heritability. However, number of branches per plant (36.50\%), pods per cluster $(20.40 \%)$ and pod length $(10.66 \%)$ showed moderate to low heritability.

Genetics advance as percentage of mean was found to be the highest for plant height $(64.05 \%)$ followed by number of clusters per plant $(53.10 \%)$, pod beating length $(51.54 \%)$, number of pods per plant $(48.80 \%)$, seed yield per plant $(46.40 \%)$, while it was moderate to low for hundred seed weight (7.40\%), seed setting percent $(6.40 \%)$, pods per cluster $(3.65 \%)$, days to first flowering $(3.40 \%)$, number of branches per plant $(2.60 \%)$, days to maturity $(1.62 \%)$ and pod length.(0.20\%).

Correlation coefficient analysis is a statistical measurement which is used to find out the degree and direction of relationship between two or more variables. Correlation coefficients were worked out at phenotypic level for twelve characters using $\mathrm{F}_{2}$ data from cross -1 and 2 . The correlation coefficients (r) obtained from this investigation are presented in table 5 .

Seed yield per plant had significant positive correlation with days to first flowering, plant height, clusters per plant, seed setting percent and pods per Cluster in both the crosses, branches per plant, pod bearing length and pods per plant in cross-1 and days to maturity, pod length and hundred seed weight in cross-2. However, pod length and hundred seed weight exhibited negative association in cross-1.

\section{Days to first flowering}

Days to first flowering had significant negative correlation with number of clusters per plant, seed setting percent and pods per cluster in both the cresses. It had positive association with days to maturity in both the crosses; pod length and hundred seed weight in cross-1 and plant height and pod bearing length in cross-2. It exhibited negative but non significant association with plant height and pod bearing length in cross- 1 .

\section{Branches per plant}

Branches per plant had significant positive correlation with number of clusters per plant, number of pods per plant and seed yield per plant in cross-1 but had negative association with days to maturity, pods per cluster, pod length and hundred seed weight in cross- 1 . In cross- 2 it had positive association with days to maturity pods, cluster, pod length and hundred seed weight.

\section{Days to maturity}

Maturity had significant positive correlation with plant height, pod bearing length, seed setting percent, pods per cluster, number of pods per plant and pod length in both the crosses. However it was also positively correlated with hundred seed weight only in cross-1.

\section{Plant height}

Significant positive association of plant height was observed with number of clusters per plant, pod bearing length, pods per cluster, number of pods per plant and pod length, in both the crosses, whereas it showed positive association with seed 
setting percent and hundred seed weight only in cross- 1 .

\section{Clusters per plant}

Significant and positive association of this character was observed with pod bearing length, seed setting per cent, pods per cluster and number of pods per plant in cross-1, while, it had significant negative association with pod length and hundred seed weight in cross- 1 and with seed setting percent in cross2.

\section{Pod bearing length}

Pod bearing length had positive and significant association with pods per cluster, pods per plant and pod length in both the crosses and with seed setting percent in cross-1. It was negatively associated with hundred seed weight in cross- 2

\section{Seed setting per cent}

It showed significant and positive association with seed yield and pods per cluster in both the crosses and with number of pods per plant in cross-1 and with hundred seed weight in cross-2. It was negatively associated with hundred seed weight in cross-1 and with number of pods per plant in cross-2 respectively.

\section{Pod per cluster}

It showed significant and positive correlation with number of pods per plant and seed yield per plant in both the crosses, but negatively associated with hundred seed weight onus in cross-2.

\section{Pods per plant}

Pods per plant had significant positive correlation with seed yield in cross-1 while, it had significant negative correlation with hundred seed weight in both the crosses.

\section{Pod length}

Pod length exhibited significant positive correlation with hundred seed weight in both the crosses and with seed yield per plant in cross-2, while, it had negative correlation with seed yield in cross- 1 .

\section{Hundred seed weight}

It had significant and positive association with seed yield per plant in cross- 2 but negative association in cross- 1 .

A sound genetic information has been an indispensable prelude for modifying the vast array of gene frequencies to enable genetic enrichment in a genotype. The presence of genetic variability is essential and pre-requisite for an effective improvement in a crop species. Besides, genetic variability, heritability which measures the relationship between phenotypic and genotypic appearance is another important consideration for the success of a breeding programme. It is obvious that the selection is usually based on phenotypic observations and the success would naturally depend upon the relationship between phenotype and the genotype.

The estimates of heritability are also useful in prediction of genetic improvement following selection and deciding suitable breeding procedures for the improvement of a crop plant. The knowledge of association between yield and yield components are useful in determining suitable selection scheme for maximum genetic gain. This information can also be used for locating the most important yield components. 
The purpose of the present investigation was to obtain the basic information which can throw light on the strategies to be adored for genetics improvement of filed pea.

The present investigation was therefore, under taken to ascertain the basic information regarding the genetic variability, heritability and inter-relationship at phenotypic levels for grain yield and its components in field pea.

Three parents used in the present investigation differing in origin showed sufficient variability for the characters under study. The treatments consisting six generations showed significant differences for all the traits in both the crosses except for number of branches per plant, hundred seed weight in cross- 1 , pods per cluster and length in cross-2. Thus it is evident from data that adequate variability was generated for carrying out the various analyses as well as fulfilling the long term objectives of selecting desirable genotypes, possessing high yield.

\section{Association analysis}

Yield is a complex character and resultant of interactions from many components. A plant breeder is therefore, always interested in finding out components which are closely associated with yield. Further, interrelationship among the characters could be of great significance to the breeder to exert selection pressure most profitably in order to make rapid yield gains. Knowledge of correlation between the components and yield may also be valuable for the breeder as an indication about the components on which selection pressure could most profitably be exercised in order to obtain an increase in yielding ability (Grafius, 1964). The interrelationships among the components often serve to compound such relationships with yield and techniques such as path analysis (Wright, 1921), have been developed which can unentangle their complex relations.
Correlations indicate linkages of characters. Study of character correlations, therefore, becomes useful in any crop improvement programme. Such studies have been done both at fixed population level i.e. parental genotypes; and segregating population level i.e.; $\mathrm{F}_{2}$ and later generations later ones are more useful and relevant since selection is generally practiced in the $\mathrm{F}_{2}$ or later generations.

In the present study study associations were

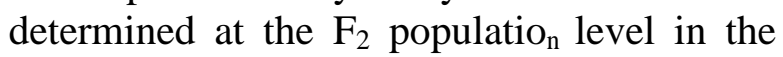
two crosses among twelve important growth and yield components. Correlation coefficient was inconsistent in different genetic back grounds.

Positise association of seed yield per plant with days to first flattering, plant height, clusters per plant, seed setting percent and pods per cluster in both the crosses; number of branches per plant and number of pods per plant in cross- 1 and days to maturity, pod length and hundred seed weight in cross- 2 as recorded in this study are in agreement with the results of Pratap et al., (1995) and Sharma and Bala (1997) for days to first flowering, plant height, pod length and seed yield.

Days to first flowering had significant positive correlation with days to maturity, pod length and hundred seed weight, are in agreement with results of Nandpuri and Kumar (1973) and Vaishnav (2000) for days to maturity and hundred seed weight.

On the other hand days to first flowering had significant and negative association with plant height, clusters per plant, pod bearing length, seed setting patent, pods per cluster and pods per plant. Similar results have also been reported by Kashyap (1979) and Narsinghani et al., (1978) for clusters per plant. 
Number of branches per plant did not show the uniform relationship with other characters. It had negative association with days to maturity, plant height, pod bearing length, pods per clusters, pod length, hundred seed weight in cross-1, while it had positive association with days to maturity, pods per cluster, pod length and hundred seed weight in cross-2. None had reported such type of relationship.

Maturity had significant positive correlations with plant height, seed setting percent, pod bearing length, pods per cluster, number of pods per plant and pod length in both the crosses; hundred seed weight only in cross- 1 . Similarly Joshi et al., (1992) and Vaishnav (2000) also reported positive association of days to maturity, branches per plant, seed setting percent and pods per cluster.

Significant positive association of plant height was observed with number of clusters per plant, pod bearing length, pods per cluster, number of pods per plant and pod length in both the crosses; seed setting percent and hundred seed weight in cross- 1 as also recorded by Chaudhary and Singh (1971), Pratap et al., (1995), Sharma and Bala (1997) and Vaishnav and Pandey (2001). On the contrary, Ranalli et al., (1981) reported negative association of plant height with pods per plant.

Significant and positive association of clusters per plant was observed with pod bearing length, seed setting per cent, pods per cluster and number of pods per plant in crossI, while it was negative with pod length and hundred seed weight; and negative with seed setting percent in cross -2 . The results clearly indicate that any increase in number of clusters per plant there may be corresponding increase in pod bearing length, pods per cluster and number of pods per plant but there could be decrease in pod and seed size. Similar results were also obtained by Makasheva and Varlkhov (1995) and Vaishnav (2000) for clusters per plant with pod beating length, pods per plant and hundred seed weight.

Pod hearing length had positive significant association with pods per cluster, number of pods per plant and pod length in both the crosses; seeds setting in cross-1; and negative with hundred seed weight in cross-2. This reveals that with increase in pod bearing length there may be increase in pods per cluster, pods per plant and pod length and ultimately seed yield.

Correlations of number of seeds per cluster and pods per plant with seed yield and between themselves were positive indicating that for improving seed yield in dry pea, the number of pods per plant must be increased. Vaishnav (2000) had also reported positive associations of these traits with yield in field pea. In accordance to this Kumar et al., (1965), Malik and Haffeez (1973). Nandpuri and Kumar (1973), Narsinghani et al., (1978). Kashhyap (1979), Yadava (1989), Joshi et al., (1992) Pratap et al., (1995). Sharma and Bala (1997), Makasheva et al., (1998). Singh and Joshi (1978), Gupta at al. (1998) Vikas and Singh (1999) and Mahanta et al., (2001). Seed setting percent showed positive relationship with pods per cluster in both the crosses but sowed inconsistency with pods per plant and hundred weight.

Seed index exhibited positive association with pod length but had negative association with pods per plant, indicating that higher number of pods may affect the seed development in field pea. Hence, emphasis on higher number of pods with longer pod size should he given while exercising selection for desirable genotype. 


\section{Int.J.Curr.Microbiol.App.Sci (2017) 6(6): 2375-2388}

Table.1 Analysis of variance for yield and its attributes in field pea

\begin{tabular}{|c|c|c|c|c|c|c|c|c|c|c|c|c|c|}
\hline $\begin{array}{l}\text { Source of } \\
\text { variation }\end{array}$ & $\mathrm{df}$ & $\begin{array}{l}\text { First } \\
\text { flower } \\
\text { (days) }\end{array}$ & $\begin{array}{l}\text { No of } \\
\text { branches } \\
\text { Plant }^{-1}\end{array}$ & $\begin{array}{l}\text { Maturity } \\
\text { (days) }\end{array}$ & $\begin{array}{l}\text { Plant height } \\
(\mathrm{cm})\end{array}$ & $\begin{array}{l}\text { No of } \\
\text { clusters } \\
\text { plant }^{-1}\end{array}$ & $\begin{array}{l}\text { Pod bearing } \\
\text { length }(\mathrm{cm})\end{array}$ & $\begin{array}{l}\text { Seed } \\
\text { setting } \\
(\%)\end{array}$ & $\begin{array}{l}\text { Pods } \\
\text { cluster }^{-1}\end{array}$ & $\begin{array}{l}\text { Number of } \\
\text { pods plant }^{-1}\end{array}$ & $\begin{array}{l}\text { Pod } \\
\text { length } \\
(\mathrm{cm})\end{array}$ & $\begin{array}{l}100 \text { seed } \\
\text { weight } \\
\text { (g) }\end{array}$ & $\begin{array}{l}\text { Seed yield } \\
\text { plant }^{-1} \\
(\mathrm{~g})\end{array}$ \\
\hline \multicolumn{14}{|c|}{ C-1: IM 9214-10 × Rachna } \\
\hline Replication & 2 & 0.0273 & 0.1088 & 0.4375 & 2.5430 & 0.4066 & 0.1486 & 0.8710 & 0.0016 & 0.6571 & 0.0720 & 0.1203 & 0.1668 \\
\hline Treatment & 5 & $2.756^{* * *}$ & 0.1622 & $3.7875^{*}$ & $1015.973 * *$ & $7.2306 * *$ & $68.227 * *$ & $22.9135^{* *}$ & $0.0386^{*}$ & $65.40 * *$ & $0.1418^{*}$ & 2.792 & $18.865^{* *}$ \\
\hline Error & 10 & 0.2664 & 0.0755 & 0.2375 & 0.5054 & 0.0733 & 0.2715 & 1.0065 & 0.0103 & 0.0745 & 0.0405 & 0.1571 & 0.1526 \\
\hline \multicolumn{14}{|c|}{ C-2: IM 9214-10 × Ambika } \\
\hline Replication & 2 & 0.6914 & 0.2338 & 0.8906 & 0.1015 & 0.06222 & 0.2271 & 0.0039 & 0.0072 & 0.2772 & 0.0816 & 0.4257 & 0.1433 \\
\hline Treatment & 5 & $2.7679 * *$ & $0.3498^{*}$ & $5.3416^{* * *}$ & $1424.687 * *$ & $7.2818 * *$ & $42.7472^{* *}$ & $21.1802 * *$ & 0.0222 & $26.9245^{* *}$ & 0.0936 & $2.1602 * *$ & $9.604 * *$ \\
\hline Error & 10 & 0.4011 & 0.1025 & 0.8666 & 0.8250 & 0.05356 & 0.7952 & 1.9200 & 0.0125 & 0.9372 & 0.0869 & 0.1424 & 0.1173 \\
\hline
\end{tabular}

*,** Significant at 5 and 1 percent level of significance 


\section{Int.J.Curr.Microbiol.App.Sci (2017) 6(6): 2375-2388}

Table. 2 Cross wise mean performance of different generations for yield and attributes in field pea

\begin{tabular}{|c|c|c|c|c|c|c|c|c|c|c|c|c|}
\hline & $\begin{array}{l}\text { First } \\
\text { flower } \\
\text { (days) }\end{array}$ & $\begin{array}{l}\text { No of } \\
\text { branches } \\
\text { Plant }^{-1}\end{array}$ & $\begin{array}{l}\text { Maturity } \\
\text { (days) }\end{array}$ & $\begin{array}{l}\text { Plant } \\
\text { height } \\
(\mathrm{cm})\end{array}$ & $\begin{array}{l}\text { Clusters } \\
\text { plant }^{-1}\end{array}$ & $\begin{array}{l}\text { Pod } \\
\text { bearing } \\
\text { length } \\
(\mathrm{cm})\end{array}$ & $\begin{array}{l}\text { Seed } \\
\text { setting } \\
(\%)\end{array}$ & $\begin{array}{l}\text { Pods } \\
\text { cluster }^{-1}\end{array}$ & $\begin{array}{l}\text { Number } \\
\text { of pods } \\
\text { plant }^{-1}\end{array}$ & $\begin{array}{l}\text { Pod } \\
\text { length } \\
(\mathrm{cm})\end{array}$ & $\begin{array}{l}100 \text { seed } \\
\text { weight } \\
(\mathrm{g})\end{array}$ & $\begin{array}{l}\text { Seed } \\
\text { yield } \\
\text { plant }^{-1} \\
\text { (g) }\end{array}$ \\
\hline \multicolumn{13}{|c|}{ C-1: IM 9214-10 × Rachna } \\
\hline $\mathrm{P}_{1}$ & 43.73 & 3.67 & 121.80 & 60.00 & 4.67 & 7.33 & 68.67 & 1.20 & 8.00 & 4.33 & 18.73 & 5.17 \\
\hline $\mathrm{P}_{2}$ & 42.20 & 3.27 & 125.20 & 76.00 & 4.80 & 18.07 & 72.97 & 1.40 & 9.93 & 4.73 & 19.43 & 5.90 \\
\hline $\mathrm{F}_{1}$ & 42.40 & 3.67 & 123.53 & 79.67 & 8.80 & 19.33 & 75.33 & 1.53 & 19.03 & 4.33 & 17.70 & 12.07 \\
\hline$\overline{F_{1}}$ & 44.00 & 3.23 & 124.33 & 63.44 & 6.73 & 17.80 & 73.77 & 1.37 & 17.00 & 4.83 & 18.65 & 6.47 \\
\hline $\mathrm{BC}_{1}$ & 44.30 & 3.20 & 123.87 & 79.60 & 6.27 & 17.87 & 77.67 & 1.40 & 8.47 & 4.67 & 20.40 & 8.07 \\
\hline $\mathrm{BC}_{2}$ & 44.33 & 3.13 & 123.80 & 85.07 & 5.33 & 20.53 & 69.33 & 1.47 & 10.60 & 4.73 & 19.85 & 6.33 \\
\hline \multicolumn{13}{|c|}{ C-2: IM 9214-10 × Ambika } \\
\hline $\mathrm{P}_{1}$ & 45.43 & 3.47 & 120.87 & 63.20 & 4.60 & 8.00 & 69.00 & 1.23 & 8.60 & 4.40 & 20.03 & 5.62 \\
\hline $\mathrm{P}_{2}$ & 45.13 & 3.67 & 124.20 & 88.67 & 4.47 & 19.53 & 69.67 & 1.43 & 16.33 & 4.70 & 19.28 & 6.40 \\
\hline $\mathrm{F}_{1}$ & 43.27 & 3.27 & 123.47 & 96.20 & 8.30 & 15.33 & 69.83 & 1.37 & 12.83 & 4.67 & 20.20 & 9.53 \\
\hline $\mathrm{F}_{1}$ & 43.47 & 3.13 & 124.60 & 65.33 & 4.13 & 15.83 & 72.17 & 1.33 & 9.37 & 4.50 & 19.81 & 6.70 \\
\hline $\mathrm{BC}_{1}$ & 43.80 & 3.53 & 124.03 & 64.17 & 4.50 & 14.00 & 72.33 & 1.43 & 13.70 & 4.43 & 20.73 & 8.30 \\
\hline $\mathrm{BC}_{2}$ & 43.33 & 3.70 & 123.33 & 71.47 & 5.17 & 13.73 & 76.17 & 1.47 & 9.93 & 4.80 & 21.73 & 10.00 \\
\hline
\end{tabular}


Table.3 Genetic parameters of variability for yield and its components in field pea

\begin{tabular}{|c|c|c|c|c|c|}
\hline$>$ Parameters & \multicolumn{2}{|c|}{ Range } & Mean & \multicolumn{2}{|c|}{ Coefficient of Variation } \\
\hline Characters & Minimum & Maximum & & Genotypic & Phenotypic \\
\hline First flower (days) & 43.33 & 46.80 & 44.70 & 02.97 & 05.96 \\
\hline No of branches plant ${ }^{-1}$ & 02.33 & 03.55 & 03.10 & 01.05 & 17.35 \\
\hline Maturity (days) & 122.00 & 125.00 & 123.80 & 00.30 & 00.91 \\
\hline Plant height $(\mathrm{cm})$ & 41.86 & 78.67 & 65.50 & 14.27 & 20.57 \\
\hline Clusters plant $^{-1}$ & 04.60 & 05.33 & 04.90 & 00.61 & 17.88 \\
\hline Pod bearing length $(\mathrm{cm})$ & 07.73 & 22.33 & 16.60 & 14.53 & 25.53 \\
\hline Seed setting (\%) & 68.00 & 76.66 & 72.00 & 00.39 & 04.80 \\
\hline Pods cluster $^{-1}$ & 01.20 & 01.60 & 01.40 & 04.11 & 08.38 \\
\hline Number of pods plant ${ }^{-1}$ & 08.00 & 14.70 & 11.10 & 00.29 & 37.84 \\
\hline Pod length $(\mathrm{cm})$ & 04.30 & 04.90 & 04.60 & 02.88 & 05.78 \\
\hline 100 seed weight $(\mathrm{g})$ & 17.40 & 22.06 & 19.80 & 04.96 & 06.02 \\
\hline Seed yield plant ${ }^{-1}(\mathrm{~g})$ & 04.50 & 09.33 & 06.80 & 08.60 & 21.31 \\
\hline
\end{tabular}

Table.4 Estimation of heritability and genetic advance in two crosses of field pea (Pisum sativum L.)

\begin{tabular}{|c|c|c|c|c|}
\hline & \multicolumn{2}{|c|}{ Cross -1} & \multicolumn{2}{|c|}{ Cross -2} \\
\hline & $\mathrm{h}^{2}(\mathrm{~ns})$ & GA \% & $\mathrm{h}^{2}(\mathrm{~ns})$ & GA \% \\
\hline First flower (days) & 75.70 & 3.73 & 66.30 & 3.40 \\
\hline No of branches plant $^{-1}$ & 52.64 & 5.36 & 36.50 & 2.60 \\
\hline Maturity (days) & 83.30 & 1.66 & 63.30 & 1.62 \\
\hline Plant height $(\mathrm{cm})$ & 99.90 & 54.20 & 98.80 & 64.05 \\
\hline Clusters plant $^{-1}$ & 97.00 & 51.30 & 97.80 & 53.10 \\
\hline $\begin{array}{l}\text { Pod bearing length } \\
(\mathrm{cm})\end{array}$ & 98.80 & 57.95 & 94.60 & 51.54 \\
\hline Seed setting $(\%)$ & 87.90 & 7.25 & 77.00 & 6.40 \\
\hline Pods cluster $^{-1}$ & 47.80 & 10.00 & 20.40 & 3.65 \\
\hline Number of pods plant ${ }^{-1}$ & 99.70 & 78.86 & 90.00 & 48.80 \\
\hline Pod length $(\mathrm{cm})$ & 45.40 & 5.65 & 10.66 & 0.20 \\
\hline 100 seed weight $(\mathrm{g})$ & 84.80 & 9.30 & 82.50 & 7.40 \\
\hline Seed yield plant $^{-1}(\mathrm{~g})$ & 97.60 & 69.20 & 96.40 & 46.40 \\
\hline
\end{tabular}


Table.5 Correlation coefficients among yield and its attributes in F2 population in two crosses of field pea in field pea (Pisum sativum L. )

\begin{tabular}{|c|c|c|c|c|c|c|c|c|c|c|c|c|}
\hline Characters & Cross & $\begin{array}{l}\text { No of } \\
\text { branches } \\
\text { Plant }^{-1}\end{array}$ & $\begin{array}{l}\text { Maturity } \\
\text { (days) }\end{array}$ & $\begin{array}{l}\text { Plant } \\
\text { height } \\
(\mathrm{cm})\end{array}$ & $\begin{array}{l}\text { No of } \\
\text { clusters }^{-1} \\
\text { plant }^{-1}\end{array}$ & $\begin{array}{l}\text { Pod bearing } \\
\text { length }(\mathrm{cm})\end{array}$ & $\begin{array}{l}\text { Seed } \\
\text { setting } \\
(\%)\end{array}$ & $\begin{array}{l}\text { Pods } \\
\text { cluster }^{-1}\end{array}$ & $\begin{array}{l}\text { Number of } \\
\text { pods plant }\end{array}$ & $\begin{array}{l}\text { Pod length } \\
(\mathrm{cm})\end{array}$ & $\begin{array}{l}100 \text { seed } \\
\text { weight } \\
(\mathrm{g})\end{array}$ & $\begin{array}{l}\text { Seed yield } \\
\text { plant }^{-1}(\mathrm{~g})\end{array}$ \\
\hline First flower (days) & $\begin{array}{l}\mathrm{C}_{1} \\
\mathrm{C}_{2}\end{array}$ & $\begin{array}{l}-0.387 * * \\
0.150\end{array}$ & $\begin{array}{l}0.285 * * \\
0.382 * *\end{array}$ & $\begin{array}{l}-0.096 \\
-0.398 * *\end{array}$ & $\begin{array}{l}-0.213^{* *} * \\
-0.396^{* *}\end{array}$ & $\begin{array}{l}-0.090 \\
-0.197 * *\end{array}$ & $\begin{array}{l}-0.408 * * \\
-0.490 * *\end{array}$ & $\begin{array}{l}-0.202 * * \\
-0.197\end{array}$ & $\begin{array}{l}-0.317 * * \\
0.087\end{array}$ & $\begin{array}{r}0.236 * * \\
-0.264 * *\end{array}$ & $\begin{array}{r}0.497 * * \\
-0.598 * *\end{array}$ & $\begin{array}{l}0.366 * * \\
0.646 * *\end{array}$ \\
\hline No of branches plant ${ }^{-1}$ & $\begin{array}{l}\mathrm{C}_{1} \\
\mathrm{C}_{2}\end{array}$ & & $\begin{array}{l}-0.423 * * \\
0.47 * *\end{array}$ & $\begin{array}{l}-0371 * * \\
0.090\end{array}$ & $\begin{array}{l}0.279 * * \\
-0.138\end{array}$ & $\begin{array}{l}-0.421 * * \\
-0.025\end{array}$ & $\begin{array}{c}-0.049 \\
0.171\end{array}$ & $\begin{array}{l}-0.181 * \\
0.239 * *\end{array}$ & $\begin{array}{l}0.206 * * \\
0.149\end{array}$ & $\begin{array}{r}-0.401 * * \\
0.457 * *\end{array}$ & $\begin{array}{r}-0.685 * * \\
0.277 * *\end{array}$ & $\begin{array}{l}0.355^{* *} \\
0.072\end{array}$ \\
\hline Maturity (days) & $\begin{array}{l}\mathrm{C}_{1} \\
\mathrm{C}_{2}\end{array}$ & & & $\begin{array}{l}0.656 * * \\
0.585 * *\end{array}$ & $\begin{array}{c}0.061 \\
-0.044\end{array}$ & $\begin{array}{l}0.721 * * \\
0.710\end{array}$ & $\begin{array}{l}0.508 * * \\
0.203 * *\end{array}$ & $\begin{array}{l}0.401 * * \\
0.211 * *\end{array}$ & $\begin{array}{c}0.205 * * \\
0.369 * *\end{array}$ & $\begin{array}{l}0.615 * * \\
0.338 * *\end{array}$ & $\begin{array}{l}0.263 * * \\
-0.129\end{array}$ & $\begin{array}{l}0.046 \\
0.271 * *\end{array}$ \\
\hline Plant height $(\mathrm{cm})$ & $\begin{array}{l}\mathrm{C}_{1} \\
\mathrm{C}_{2}\end{array}$ & & & & $\begin{array}{l}0.376 * * \\
0.575^{*} *\end{array}$ & $\begin{array}{c}0.953 * * \\
0.837 * *\end{array}$ & $\begin{array}{l}0.482 * * \\
0.026\end{array}$ & $\begin{array}{l}0.752 * * \\
0.438 * *\end{array}$ & $\begin{array}{l}0.248 * * \\
0.662 * *\end{array}$ & $\begin{array}{l}0.331 * * \\
0.393 * *\end{array}$ & $\begin{array}{l}0.298 * * \\
-0.098\end{array}$ & $\begin{array}{l}0.471 * * \\
0.520 * *\end{array}$ \\
\hline Clusters plant $^{-1}$ & $\begin{array}{l}\mathrm{C}_{1} \\
\mathrm{C}_{2}\end{array}$ & & & & & $\begin{array}{l}0.444 * * \\
0.082\end{array}$ & $\begin{array}{r}0.723 * * \\
-0.196 * *\end{array}$ & $\begin{array}{l}0.543 * * \\
0.035\end{array}$ & $\begin{array}{l}0.847^{* * *} \\
0.129\end{array}$ & $\begin{array}{l}-0.210 * * \\
0.047\end{array}$ & $\begin{array}{l}-0.552 * * \\
0.122\end{array}$ & $\begin{array}{l}0.908 * * \\
0.590 * *\end{array}$ \\
\hline Pod bearing length $(\mathrm{cm})$ & $\begin{array}{l}\mathrm{C}_{1} \\
\mathrm{C}_{2}\end{array}$ & & & & & & $\begin{array}{l}0.586 * * \\
0.008\end{array}$ & $\begin{array}{l}0.750 * * \\
0.522 * *\end{array}$ & $\begin{array}{l}0.438 * * \\
0.703 * *\end{array}$ & $\begin{array}{l}0.428 * * \\
0.277 * *\end{array}$ & $\begin{array}{l}0.159 \\
-0.312 * *\end{array}$ & $\begin{array}{l}0.441 * * \\
0.168\end{array}$ \\
\hline Seed setting (\%) & $\begin{array}{l}\mathrm{C}_{1} \\
\mathrm{C}_{2}\end{array}$ & & & & & & & $\begin{array}{l}0.504 * * \\
0.411 * *\end{array}$ & $\begin{array}{r}0.701 * * \\
-0.221 * *\end{array}$ & $\begin{array}{l}0.131 \\
0.104\end{array}$ & $\begin{array}{r}-0.334 * * \\
0.704 * *\end{array}$ & $\begin{array}{l}0.665 * * \\
0.572 * *\end{array}$ \\
\hline Pods cluster $^{-1}$ & $\begin{array}{l}\mathrm{C}_{1} \\
\mathrm{C}_{2}\end{array}$ & & & & & & & & $\begin{array}{l}0.436 * * \\
0.464 * *\end{array}$ & $\begin{array}{r}0.165 \\
-0.030\end{array}$ & $\begin{array}{l}-0.055 \\
0.208 * *\end{array}$ & $\begin{array}{l}0.509 * * \\
0.432 * *\end{array}$ \\
\hline Number of pods plant $^{-1}$ & $\begin{array}{l}\mathrm{C}_{1} \\
\mathrm{C}_{2}\end{array}$ & & & & & & & & & $\begin{array}{r}-0.055 \\
0.013 \\
\end{array}$ & $\begin{array}{l}-0716 * * \\
-0.310 * *\end{array}$ & $\begin{array}{l}0.665 * * \\
0.053\end{array}$ \\
\hline Pod length $(\mathrm{cm})$ & $\begin{array}{l}\mathrm{C}_{1} \\
\mathrm{C}_{2}\end{array}$ & & & & & & & & & & $\begin{array}{l}0.392 * * \\
0.228 * *\end{array}$ & $\begin{array}{r}-0.313 * * \\
0.342 * *\end{array}$ \\
\hline 100 seed weight $(\mathrm{g})$ & $\begin{array}{l}\mathrm{C}_{1} \\
\mathrm{C}_{2}\end{array}$ & & & & & & & & & & & $\begin{array}{r}-0.462 * * \\
0.668 * *\end{array}$ \\
\hline
\end{tabular}

*, ** Significant at 5 and 1 percent level of significance $\mathrm{C}_{1}=$ Cross-1 (IM 9214-10 $\times$ Rachna), $\mathrm{C}_{2}=$ Cross-2 (IM 9214-10 $\times$ Ambika) 
Vaishnav (2000) had also reported positive correlation between pod length and seed size in pea but no relation between pod number and seed size.

Results of association studies clearly gave an indication that correlations among the component characters were somewhat inconsistent depending upon the genetic back ground of the population under study. However, relationships of the component characters with seed yield in general, were consistent and positive, indicating that for yield improvement in pea, plant breeders should pay attention on these attributes while exercising the selection in segregating population.

\section{References}

Arulbalachandran D, Mullainathan L, Velu S and Thilagavathi C.2010. Genetic variability, heritability and genetic advance of quantitative traits in black gram by effects of mutation in field trial. African Journal of Biotechnology 9(19): 2731-2735.

Bhadru, D. (2010). Studies on genetic parameters and interrelationships among yield and yield attributing traits in pigeon pea (Cajanus cajan L.). Legume Res., 33 (1): 23-27.

Burton, G.W. (1952). Quantitative inheritance in grasses. In proceedings of 6th International Grassland Congress Ames, Iowa,USA pp 227-283.

Burton, GW and de Vane EH. 1953. Estimating heritability in tall fescue (Festuca arundinacea) from replicated clonal material.Agronomy Journal 45: 471-481.

Chaudhary DK and Sharma RR. 2003. Genetic variability, correlation and path analysis for green pod yield and its components in garden pea. Indian Journal of Horticulture 60(3): 251-256.
Dewey, D.R. and Lu, K.H.A. (1959). Correlation and path coefficient analysis of components in crested wheat grass seed production. Agron.J., 51:55-518

Dhulgande GS, Dhale DA, Pachkore GL and Satpute RA. 2011.Mutagenic effectiveness and efficiency of gamma rays and ethylmethanesulphate in pea (Pisum sativum L.). Journal of Experimental Sciences 2(3): 07-08.

Filippetti A. 1980. Variation and interrelationships between yield and other qualitative and quantitative characters in mutant lines of two varieties of pea (Pisum sativum L.). Sementi Elette 26 (3): 5-14.

Food and Agriculture Organisation (2008). FAO Statistical Database on agriculture. FAO, Rome, Italy.

Gottschalk W. 1968. Simultaneous mutation of closely linked genes: A contribution to the interpretation of 'Pleiotropic' gene action. In: Mutations in Plant Breeding. II. IAEA Proc Ser (Proceedings of Panel meeting, Vienna, 1967), pp 97-109.

Grafius JE. 1959. Genetic and environmental relationship of components of yield, maturity and height in F2-F3 soybean populations. Iowa State College Journal of Science 30: 373-374.

Hanson, G.H., Robinson, H.F. and Comstock, R.E. (1956).Biometrical studies of yield in segregating population of Korean Lespedeza. Agron. J. 46: 267-282

Jaranowski J and Mickle A. 1985. Mutation breeding in peas. Mutation Breeding Review 2: 1-23.

Johnson, H.W., Robinson, H.F. and Comstock, R.E. (1955). Estimates of genetic and environment variability in soyabean. Agron.J., 47: 314-318.

Khan MR and Qureshi AS. 2001. Quantitative variations induced by gamma irradiation and gibberellic acid 
in M1 generation of chickpea. Sarhand Journal of Agriculture 17(3): 367-371.

Kumar B, Lakhi R, Singh JD and Singh B. 2003. Correlations and pat $\mathrm{h}$ coefficient analysis in pea (Pisum sativum L.). Progressive Agriculture 3 (1/2): 141142.

Kumar D and Ojha CBC. 1997. Genetic variability and correlation studies for grain yield and its components in pea (Pisum sativum L.). Journal of Soils and Crops 7 (2): 139-142.

Kumaran SS, Natrajan S and Thamburaj S. 1995. Genetic variability in pea (Pisum sativum L.). South Indian Horticulture 43 (1-2):10-13.

Lal N and Mishra R. 2006. Induced genetic variability and divergence in M3 generation in mungbean. Indian Journal of Pulses Research 19(1): 47-49.

Miller, D.A., Williams, J.C., Robinson, H.F. and Comstock, K.B.(1958). Estimates of genotypic and environmental variances and covariances in a planned cotton and their implications in selection.

Momin BW and Misra RC. 2004. Induced variability, character association and path-coefficient analysis in mutant cultures of green gram. Environment and Ecology 22(3): 608-611.

Nandanwar RS, Patil AN and Wakode MM. 2001. Mutagenic effectiveness and efficiency of gamma rays, ethylmethane sulphonate and hydroxylamine in mungbean (Vigna radiata (L.) Wilczek.) in M2 generation. Journal of Soils and Crops 11(2):223-225.

Panse VG and Sukhatme PV. 1978. Statistical method for agricultural workers, ICAR publication (3rd ed.), New Delhi, 235-247.

Panse, V.G. and Sukhatme, P.V. (1967). Statistical method for agricultural workers. Indian Council of agricultural
Research, New Delhi.

Patel, P.J.; Patel, N.H.; Prajapati, B.H.; Tikka, S.B.S. and Patel,P.T. 2006. Correlation and path-analysis in fieldpea. Indian Journal of Pulses Research 19 (1): 109-110.

Patil GP and Wakode MM. 2011. Induced genetic variability for quantitative traits in M2 generation in soybean by mutagens. Current Botany 2(1): 10-14.

Searle SR. 1961. Phenotypic, Genetic and Environmental Correlations. Biometrics 17(3): 474-480.

Sharma VK and Bora L. 2013. Studies on genetic variability and heterosis in vegetable pea (Pisum sativum L.) under high hills condition of Uttarakhand, India. African Journal of Agricultural Research 8(18): 1891-1895.

Singh A, Singh S and Babu JDP. 2011. Heritability, character association and path analysis studies in early segregating population of field pea (Pisum sativum L. var. arvense). International Journal of Plant Breeding and Genetics 5(1): 86 -92.

Singh AK. 2009. Induced genetic variability in M3 generation of mungbean. Journal of Food Legumes 22(3): 162-165.

Singh G, Sareen PK, Saharan RP and Singh A. 2001. Induced variability 118 in mungbean [Vigna radiata (L.) Wilczek]. Indian Journal of Genetics and Plant Breeding 61(3): 281-282.

Singh K and Singh MN. 2013. Effectiveness and efficiency of Gamma rays and Ethyl Methane Sulphonate (EMS) in mungbean. Journal of Food Legumes 26(3 \& 4): 25-28.

Singh M and Singh VP. 2003. Correlation and path coefficients analysis in induced mutant lines of urdbean. Indian Journal of Pulses Research 16(1):59-62.

Singh, A., Singh, S. and Prasad Babu, J.D. (2011). Heritability, character association and path analysis studies in 
early segregating population of field pea (Pisum sativum L. var. arvense). Internat. J. Plant Breed. Genet., 5(1): 86-92.

Singh, J.P. and Singh, I.P. (2005). Studies on correlation and path coefficient analysis in field pea (Pisum sativum L.).Nat. J. Pl. Imp., 7(1): 59-60

Singh, J.P. and Singh, I.P. (2006). Genetic variability, heritability, expected genetic advance and character association in field pea (Pisum sativum L.). Legume Res., 29 (1): 65-67.

Sridevi A and Mullainathan N. 2012. Effect of gamma rays and ethyl methane sulphate (EMS) in M3 generation of blackgram (Vigna mungo L. Hepper).
African Journal of Biotechnology 11(15):3548-3552.

Srivastava JP, Singh HN and Singh SP. 1972. Genetic studies on yield components in pea (Pisum sativum L.) var. (arvense Poir). Indian Journal of agricultural Sciences 42: 1001-1004.

Tiwari G and Lavanya G R. 2012. Genetic variability, character association and component analysis in F4 generation of field pea. Karnataka Journal of agricultural Sciences 25(2): 173-

Tyagi MK and Srivastava CP. 2002. Genetic variability and correlation among yield and yield characters over two environments in pea. Indian Journal of Agricultural Research 36(1): 53-56.

\section{How to cite this article:}

Meena, B.L., S.P. Das, B.K. Kandpal and Nagchan, S.V. 2017. Genetic Estimates and Character Association Studies in Field Pea (Pisum sativum L.). Int.J.Curr.Microbiol.App.Sci. 6(6): 2375-2388. doi: https://doi.org/10.20546/ijcmas.2017.606.282 